\title{
Training of Skilled and Unskilled Labours for Handling Preliminary Machinaries in Manufacturing Units
}

\author{
W.Porselvi, B.Venkata Srilatha, M.Sankar.
}

\begin{abstract}
India has gotten one of the world's quickest developing information based economies because of monstrously plenteous capital. Notwithstanding the vehement pressure laid on instruction and preparing in this nation, there is as yet a lack of talented labor to address the mounting needs and requests of the economy. Accordingly, the administration of India has been endeavoring to start and accomplish formal/casual aptitude improvement of the working populace through instructive/expertise preparing and other up and coming learning strategies. Government and private foundations offer expertise preparing programs, these projects experience the ill effects of deficient quality and importance, absence of coordination inside the division, and inadequate regard for work showcase results.

In this foundation, legislature of India has distinguished aptitude improvement as one of the need divisions and taken up a few activities to address the difficulty of development of preparing limit with speed, excellent models and supportability. In this venture, the future work depends more on aptitudes of individuals not as a result of the capability degree they groups in their hand. The government has numerous expertise advancement programs Pradhan Mantri Kaushal Vikas Yojana (PMKVY), Skill India.

Representatives can add to associations achievement in the event that they are prepared to perform to industry standard. Enlisting incompetent work, those with constrained capability and preparing may appear to set aside your business cash. Be that as it may, incompetent laborers, especially for talented positions, can have weakness identified with creation, life span and generally organization execution. These are primary explanations behind work cutback in numerous modern areas. Key words: Labour, poverty, Education, Integration, Development
\end{abstract}

\section{INTRODUCTION}

Expertise improvement is a significant driver to address destitution decrease by improving employability, efficiency and helping feasible and in-selective development. It encourages a cycle of high efficiency, expanded work openings, salary development and advancement.

Gifted Labor:

have explicit getting ready or an insightful scope of

Revised Manuscript Received on December 30, 2019.

W.Porselvi, Assistant Professor, Department Of Science and Humanities,Bharath Institution Of Higher Education And ResearchTamilNadu,India. Email: porselviwilson@gmail.com

B.Venkata Srilatha, Assistant Professor, Department Of Science and Humanities,Bharath Institution Of Higher Education And Research

ResearchTamilNadu,India. Email bvsrilatha27@gmail.com

M.Sankar, Assistant Professor, Department Of Science and Humanities,Bharath Institution Of Higher Education And Research ResearchTamilNadu,India. Email: sankar06.phd@gmail.com
Talented work implies work that requires workers who

capacities to play out the work. These workers can be either active or desk area workers, with changed degrees of planning or guidance. Profoundly capable pros may fall under the order of specialists, rather than talented work, for instance, masters and lawful advisors. Occurrences of capable work occupations are: circuit analyzers, law prerequisite authorities, PC directors, cash related specialists, and administrative pros. Some skilled work occupations have become so explicit that there are expert inadequacies.

\section{A. Incompetent Labor:}

House keepers have a particular arrangement of assignments to perform and stock administration obligation while staple agents must oversee cash and figure out how to stock retires appropriately.

\section{B. Semi-or Mid-Skill Labor:}

Be that as it may, they don't require exceptionally particular abilities. Instances of mid-expertise occupations incorporate truck drivers, typists and client support agents. These occupations for the most part require in excess of a secondary school recognition, however not exactly a higher education.[1]-[5]

\section{OBJECTIVES OF SKILL DEVELOPMENT}

- To propose an organized and down to business answer for address the absence of significant abilities among the present and potential workforce of India.

- To convey an organized, maintainable and adaptable structure to bestow abilities to the jobless, underemployed, uncertified and un-benchmarked laborers.

- To dovetail into a bigger national structure of human asset advancement to meet the dynamic needs of industry and the economy.[6]-[10]

\section{SUMMARY OF THE STUDY SKILL DEVELOPMENT IN SCHOOLS}

Reconciliation of expertise advancement and instruction is fundamental for skilling to take wings. Expertise improvement will stay a fantasy whenever helped out in detachment through focuses alone. It must be imported in schools nearby scholastics. Evolusion of expertise preparing as indicated by the student's age The employable aptitudes

Published By: 
separated from the center abilities as referenced above ought to be acquainted with school understudies since the beginning of 6-7 years onwards in a gradual way.

Grade school (classes 1 to 5) (age 6 to 11): Communication abilities, demeanor, versatility and IT aptitudes. Center school (classes 6 to 8) (age 11 to 14): Above aptitudes in addition to self-administration, collaboration, imagination. Optional training (classes 9 to 10) (age 14 to 15): Above abilities in addition to stretch the executives, self-motivation.Upper auxiliary (classes 11 to 12 ) (age 16 to 17): Above aptitudes in addition to activity, relational affectability. Advanced education (graduation or expert programs): Above abilities in addition to business mindfulness, critical thinking, deep rooted learning.[11]-[15]

\section{A. Collegial Course}

Classes that are NCAA(National Assessment and Accrediation council) core courses include:

English: English 1-4, American Literature, creative writing. Maths: Algebra 1-3, Geometry, statistics.

Natural of physical science: biology, chemistry, physics.

Social science: American History, civics, government.

\section{B. Vocational Courses In India}

Investigation of professional course is characterized as the functional aptitudes given to an understudy or individual in a specific field. It by and large targets getting ready people for a particular vocation during the course and aides in overhauling the profession. Projects under professional extraordinarily customized with the goal that an individual can be totally work prepared. Professional course by and large guarantees that an individual has important to play out a specific calling.

Professional instruction or ability based training are in sure teaches which empowers understudies to get aptitudes which are generally non-scholarly and completely identified with explicit exchange, occupation or livelihood. They are otherwise called Technical Education. Profession and Technical Education (CTE) or professional Education and Training (VET) as they straightforwardly create skill in a specific gathering of methods or innovation through manual or pragmatic exercises. [16]-[19]

Professional courses are principally structured so that they bestow an intensive application-based study wherein hypothetical ideas of a field are not examined autonomously yet are subjected to the comprehension of techno-operational parts of explicit work.

\section{RESULTS\& DISCUSSION}

In india80\% of new entrants to workforce have no opportunity for skill training. Against 12.8 million per annum new entrants to the workforce the existing training courses are very immediate in their motivation and

capacity is 3.1 million per annum. About $2 \%$ of existing workforce has skill training against $96 \%$ in Korea, $75 \%$ in German.

\section{A. Skill India:}

Highlights of 'Aptitude India'

The complement is to mastery the youngsters in such a way along these lines, that they get work and besides improve venture.

Gives getting ready, support and bearing for all occupations that were of standard sort like carpenters, shoemakers, welders, metalworkers, bricklayers, therapeutic specialists, tailors, weavers, etc.

More emphasis will be given on new regions like land, improvement, transportation, material, pearl industry, diamonds organizing, banking, the movement business and various fragments, where capacity progression is lacking or nil.

The course arrangement of 'Inclination India' would be imaginative, which would consolidate games, bundle talks, gatherings to produce new thoughts, practical experiences, logical examinations, etc.

\section{EFFECTIVE COMMUNICATION}

It is vital to impart adequately in dealings to guarantee you accomplish your objectives. Correspondence is additionally significant inside the business. Powerful correspondence can cultivate a decent working connection among you and your staff, which can thusly improve confidence and efficiency..

\section{SECTOR JOB IN IT SECTOR:}

- The job market in India is warming up in 2018

- Jobseekers can expect to see fatter paychecks, faster.

- Even pre-placement offers (PPOs) are on the rise in B-schools.According to a Naukri Company ,Hiring has risen by $\mathbf{1 0 - 2 0 \%}$ across colleges.Average salaries have increased by $\mathbf{2 0 \%}$ in top B-schools.

\section{CONCLUSION}

"Introduction to skill training at young age will by all means give the student an opportunity to explore various options and accordingly, narrow down on a vocation of his/her likings." Skill development must be made compulsory for all young age students in school levels.

- The government must take necessary measures to provide basic skill training and opportunities to students like other subjects.

- The Indian government must change the educational system to provide more importance for skill development in school level.

- Vocational courses should be made compulsory in India like other countries eg. Australia.

- School dropouts can be reduced considerably in future periods.

- Skill development training and programme helps the dropouts to survive with skills acquired by them in schools.[20]-[24] 


\section{REFERENCES}

1. Vasanthi, S. \& Rabiyathul Basariya, S. 2019, "Influence of value analysis and cross training in industry", International Journal of Engineering and Advanced Technology, vol. 8, no. 6, pp. 1810-1811.

2. Velvizhi, R., Sri Gowtham, S. \& Jeya Priya, D. 2019, "Examination of early feedbacks for effective product retailing on E-commerce websites", International Journal of Engineering and Advanced Technology, vol. 8, no. 6 Special Issue 2, pp. 703-706.

3. Anuradha, C., Pothumani, S. \& Kavitha, R. 2019, "A novel method towards E-commerce", International Journal of Engineering and Advanced Technology, vol. 8, no. 6 Special Issue 2, pp. 535-538.

4. Thomas, J. \& Rabiyathul Basariya, S. 2019, "A study on the issues of financial ratio analysis", Indian Journal of Public Health Research and Development, vol. 10, no. 3, pp. 1079-1081.

5. Ramachandran, S. \& Rabiyathul Basariya, S. 2019, "Online marketing study on customer satisfaction and relationship", Indian Journal of Public Health Research and Development, vol. 10, no. 3, pp. 1072-1078.

6. Priya, R., Vinothini, G. \& Cor Jesu, C.D. 2019, "The mentor-protégé relationship for professional growth", Journal of Advanced Research in Dynamical and Control Systems, vol. 11, no. 9 Special Issue, pp. 1110-1119.

7. Jannifer Rani, N., Bina Pani, S. \& Nimisha, N.S. 2019, "A study on money back polices available in LIC", Journal of Advanced Research in Dynamical and Control Systems, vol. 11, no. 9 Special Issue, pp. 833-839

8. Saillaja, V., Jhansi Rani, K. \& Catherine, R. 2019, "Global marketing management planning and organization", Journal of Advanced Research in Dynamical and Control Systems, vol. 11, no. 9 Special Issue, pp. 489-493.

9. Saillaja, V., Jhansi Rani, K. \& Catherine, R. 2019, "The new phase of marketing information system", Journal of Advanced Research in Dynamical and Control Systems, vol. 11, no. 9 Special Issue, pp. 482-488.

10. Thoufiqulla \& Raju, D.V. 2019, "Perception of indian investor towards investment in mutual funds with special reference to mip funds", Journal of Advanced Research in Dynamical and Control Systems, vol. 11, no. 5, pp. 177-183.

11. Jasmine, K.R.M. \& Basariya, S.R. 2018, "A study on the customers benefits on mutual funds", International Journal of Civil Engineering and Technology, vol. 9, no. 4, pp. 45-48.

12. Vasanthi, S. \& Basariya, S.R. 2019, "Pros and cons of on the job training versus off the job training", International Journal of Scientific and Technology Research, vol. 8, no. 10, pp. 671-674.

13. Pavithra, J. \& Ganesan, M. 2016, "A study on awareness and impact of micro-financial schemes", International Journal of Applied Business and Economic Research, vol. 14, no. 8, pp. 5449-5460.

14. Pavithra, J., Dilli Babu, P. \& Ambuli, T.V. 2014, "A study on budgetary control at Maruti Service Masters, Chennai", International Journal of Applied Business and Economic Research, vol. 12, no. 2, pp. 151-161.

15. Gunaraja, T.M. \& Venkatrama Raju, D. 2018, "Determining factors of organisational climate with reference to leadership styles", International Journal of Mechanical Engineering and Technology, vol. 9, no. 9, pp. 1327-1332.

16. Gunaraja, T.M. \& Venkatrama Raju, D. 2018, "The role of job satisfaction and training of employees in determining organisational climate of a selected industry", International Journal of Civil Engineering and Technology, vol. 9, no. 8, pp. 1266-1269.

17. Aarathy, T.S. \& Raju, D.V. 2018, "Performance appraisal and its effects on employees with respect to it sector in Chennai city", International Journal of Civil Engineering and Technology, vol. 9, no. 6, pp. 1535-1538.

18. Aarathy, T.S. \& Raju, D.V. 2018, "Employee perception towards performance appraisal system in IT sector", International Journal of Mechanical Engineering and Technology, vol. 9, no. 5, pp. 131-135.

19. Porselvi, W., Jublee, D. \& Sivanesan, G. 2018, "A study on factors influencing adoption of technology and innovation in banking industry, tamilnadu, India", International Journal of Mechanical Engineering and Technology, vol. 9, no. 5, pp. 789-800.

20. Akessa, G.M. and Dhufera, A.G., 2015. Factors That Influences Students Academic Performance: A Case of Rift Valley University, Jimma, Ethiopia. Journal of Education and Practice, 6(22), pp.55-63.

21. Miller, G. and Shih, C.C., 1999. A faculty assessment of the academic rigor of on-and off-campus courses in agriculture. Journal of Agricultural Education, 40, pp.57-65.

22. Tsinidou, M., Gerogiannis, V. and Fitsilis, P., 2010. Evaluation of the factors that determine quality in higher education: an empirical study. Quality Assurance in education, 18(3), pp.227-244.

23. Farooq, M.S., Chaudhry, A.H., Shafiq, M. and Berhanu, G., 2011. Factors affecting students' quality of academic performance: a case of secondary school level. Journal of quality and technology management, 7(2), pp.1-14.

24. Fitsilis, P., Gerogiannis, V. and Anthopoulos, L., 2014. Ontologies for software project management: a review. Journal of Software Engineering and Applications, 7(13), p.1096.

25. Adams, J.D. and Jaffe, A.B., 1996. Bounding the effects of R\&D: an investigation using matched establishment-firm data(No. w5544). National bureau of economic research.

\section{AUTHORS PROFILE}

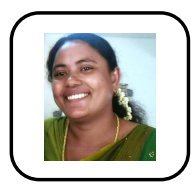

W.Porselvi, Assistant Professor, Department Of Science and Humanities,Bharath Institution Of Higher Education And ResearchTamilNadu,India

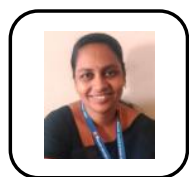

B.Venkata Srilatha, Assistant Professor, Department Of Science and Humanities,,Bharath Institution Of Higher Education And Research TamilNadu,India

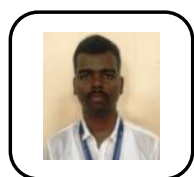

M. Sankar, Assistant Professor, Department Of Science and Humanities,Bharath Institution Of Higher Education And Research ResearchTamilNadu,India. 